\title{
Florida's Citrus Canker Eradication Program (CCEP): Summary of Annual Costs and Benefits ${ }^{1}$
}

\author{
Marisa L. Zansler, Thomas H. Spreen and Ronald P. Muraro²
}

Rapid expansion and integration of international trade, increased tourism, and changes in methods of production in recent decades have increased the likelihood of the introduction of invasive species to U.S. (United States) agriculture. Invasive species can have adverse environmental and/or economic impacts when introduced into a region. Economic impacts include marketing, production, and trade implications.

One such invasive species imposing adverse economic impacts to the Florida citrus industry is a bacterial disease known as citrus canker (caused by Xanthomonas axanopodis pv. citri). Citrus canker causes lesions on the leaves, stems, and fruit of citrus trees. The disease adversely affects the proportion of fruit intended for the fresh market, serves to weaken citrus trees, and leads to a reduction in yields and higher costs of production.

The Citrus Canker Eradication Program (CCEP) was implemented in the mid-1990s in an attempt to establish guidelines for averting the spread of the disease. Currently there is no biological or chemical cure for citrus canker. All infected trees and citrus trees within a radius of 1900 feet of an infected tree must be eradicated (1900-foot rule). On-site decontamination of grove workers, field equipment, and packinghouses is also mandatory.

The current effort to eradicate citrus canker from the industry, the CCEP, has been mired in controversy associated with public opinion and legal action. A benefit-cost analysis was conducted to determine whether the CCEP is, indeed, a useful policy tool in combating the economic ramifications associated with citrus canker.

In the analysis presented in this paper, the benefits of the CCEP are estimated through an analysis of the Florida citrus industry under the scenario that citrus canker has become established. All other factors are held constant. The estimated net change in revenue in the fresh and processed markets and the additional costs of production were measurements of the predicted benefits.

1. This is EDIS document FE532, a publication of the Department of Food and Resource Economics, Florida Cooperative Extension Service, Institute of Food and Agricultural Sciences, University of Florida, Gainesville, FL. Published March 2005. Please visit the EDIS website at http://edis.ifas.ufl.edu.

Note: This is one of a series on the economic impacts of citrus canker on Florida's citrus industry. The series is available at: http://edis.ifas.ufl.edu/TOPIC_CCEP

2. Marisa L. Zansler, Economist, Policy Analysis and Development, USDA/APHIS, Washington, D.C.; Thomas H. Spreen, Professor and Chair, Department of Food and Resource Economics, University of Florida, Gainesville, FL; and Ronald P. Muraro, Professor and Extension Economist, Department of Food and Resource Economics, Citrus Research and Education Center, Lake Alfred, FL, Florida Cooperative Extension Service, Institute of Food and Agricultural Sciences, University of Florida, Gainesville, FL.

The Institute of Food and Agricultural Sciences (IFAS) is an Equal Employment Opportunity - Affirmative Action Employer authorized to provide research, educational information and other services only to individuals and institutions that function without regard to race, creed, color, religion, age, disability, sex, sexual orientation, marital status, national origin, political opinions or affiliations. For information on obtaining other extension publications, contact your county Cooperative Extension Service office. Florida Cooperative Extension Service / Institute of Food and Agricultural Sciences / University of Florida / Larry R. Arrington, Interim Dean 
A model of the world orange juice market was originally developed at the University of Florida in 1989 (McClain) and later modified in 2003 (Spreen, Brewster, and Brown). This model is a spatial equilibrium of the world orange juice market with implicit supply. Approximately 96 percent of Florida's orange crop is sent to the processing sector; therefore, this model considers only the world processed orange market when considering Florida's orange crop (FASS, 2000). The predominant varieties in the processed orange juice market are early-midseason and Valencia varieties. Early-midseason varieties include Hamlin and Pineapple oranges.

A model of the Florida grapefruit market was originally developed at the University of Florida in 1991 (Pana) and later modified in 1995 (Buzby and Spreen). This model is a spatial equilibrium model of the Florida grapefruit market, which assimilates supply and demand in an optimization problem and generates equilibrium prices and quantities (Buzby and Spreen, 1995). The grapefruit market differs from the world orange juice market in three fundamental ways:

1. Florida is the dominant supplier of grapefruit in the world, accounting for nearly 50 percent of world production (FAO).

2. There is a greater degree of uncertainty as to whether grapefruit are intended for the fresh or processed markets

3. White seedless and red seedless grapefruit varieties are treated separately in the fresh market.

\section{Processed Oranges}

In Table 1, the net change in on-tree revenue for the processed orange juice market is summarized under the conditions associated with an industry with endemic citrus canker. The processed orange juice market is estimated to incur an overall on-tree revenue loss of \$20.4 million. Early-midseason varieties are estimated to experience the greatest revenue loss at \$20.3 million, while Valencia oranges are estimated to experience a net loss of $\$ 99,000$.
In Table 2, the net change in F.O.B. revenue for the processed orange juice market is summarized when citrus canker is endemic. Under the conditions associated with an industry with endemic citrus canker, the processed orange juice market is estimated to incur an overall F.O.B. revenue loss of \$35 million.

Table 3 illustrates the estimated net change in the cost of producing processed oranges in an endemic citrus canker industry. Under such a scenario, the overall cost of producing oranges intended for the processed market is estimated to increase by approximately $\$ 14.4$ million. The cost of producing early-midseason varieties, which are highly susceptible to citrus canker, is estimated to increase by roughly $\$ 8.2$ million. The cost of production of Valencia oranges is estimated to increase by $\$ 6.2$ million.

\section{Fresh and Processed Grapefruit}

Shown in Table 4 is the estimated net change in on-tree revenue of fresh and processed red seedless and white seedless grapefruit markets under conditions associated with an industry when citrus canker is introduced and becomes endemic. Fresh and processed grapefruit growers are estimated to incur an overall revenue net loss of $\$ 13.2$ million. On-tree revenue from fresh red seedless grapefruit sales is estimated to experience a $\$ 6.8$ million net gain in revenue, while on-tree revenue from fresh white seedless grapefruit sales is estimated to experience a $\$ 1.1$ million net loss. Revenue from processed red seedless and white seedless grapefruit sales is expected to decrease by $\$ 8.8$ million and $\$ 10.2$ million, respectively. Overall, red seedless grapefruit on-tree revenue (fresh and processed) experiences a $\$ 1.9$ million net loss, and white seedless grapefruit (fresh and processed) on-tree revenue experiences an $\$ 11.3$ million net loss.

In Table 5, the estimated net change in F.O.B. revenue for the fresh red seedless and white seedless grapefruit across world markets is summarized under the conditions associated with an industry with endemic citrus canker. Net F.O.B. revenues in the grapefruit market are estimated to experience an overall net loss of $\$ 71.5$ million. The largest impact is 
in the fresh red seedless grapefruit market, with an estimated net loss of $\$ 52.3$ million, mostly due to the loss of the European fresh market and a substantial increase in the Japanese F.O.B. price. This loss greatly offsets the gain in F.O.B. revenue estimated for the U.S. and Canadian markets. The fresh white seedless grapefruit market is estimated to experience an overall net loss of $\$ 19.2$ million. Again, the combined impact of the loss of European market access and an increase in the Japanese F.O.B. price offset the gain in estimated F.O.B. revenues for the U.S. and Canadian markets.

The estimated net change in production costs of red seedless and white seedless grapefruit intended directly for the processed market (field run) sent to the packinghouse in an endemic citrus canker industry is shown in Table 6. Production costs of field run grapefruit varieties are expected to decline by $\$ 1.4$ million, assuming citrus canker becomes established in Florida.

Production costs of the two grapefruit varieties intended for the packinghouse increase substantially by $\$ 46$ million for red seedless grapefruit and $\$ 28$ million for white seedless grapefruit. The overall cost of producing grapefruit in Florida is estimated to increase by approximately $\$ 72.7$ million.

\section{Specialty Citrus Fruit}

Under the conditions associated with an industry with endemic citrus canker, fresh and processed specialty fruit processors experience on-tree revenue gains in excess of $\$ 44.5$ million due to a significant increase in prices (Table 7). The fresh market for specialty fruits is estimated to experience a $\$ 43.1$ million (Table 7a) net gain in revenue. The processed market for specialty fruit is expected to experience net gain in revenue of $\$ 1.3$ million (Table $7 b$ ).

The estimated net change in F.O.B. revenues for specialty citrus fruit associated with endemic citrus canker is reported in Table 8. Early and honey tangerines are estimated to experience a net gain in F.O.B. revenues by $\$ 8.4$ million and $\$ 6.1$ million, respectively. Navel oranges are estimated to experience a net loss of $\$ 3.6$ million. The overall net change in F.O.B. revenue for specialty citrus is a $\$ 10.9$ million gain.
In Table 9, the estimated net change in the production costs of specialty fruit sent to the packinghouse in an endemic citrus canker industry are shown. Production costs for packinghouses of early tangerines, honey tangerines, navel oranges, temple oranges, and tangelos are estimated to increase by $\$ 13$ million, $\$ 17.8$ million, $\$ 34.3$ million, $\$ 3.7$ million, and $\$ 13.4$ million, respectively. The total change in F.O.B. costs of production for specialty varieties increase by $\$ 82.2$ million.

\section{Economic Implications of Endemic Citrus Canker in Florida}

\section{Production Implications}

Endemic citrus canker is estimated to have several economic impacts on the production of Florida citrus. Based on scientific evidence from previous studies, fruit drop is the primary factor in anticipated yield losses (Koizumi, 1985; Graham and Gottwald, 1991). Furthermore, the level of susceptibility by variety translates into greater yield losses for some citrus varieties over others (Gottwald, et al, 1993; Graham, 2001). In addition to yield loss, a producer will incur additional production costs associated with an endemic citrus canker industry. Additional costs include copper sprays and windbreaks to mitigate the spread of the disease. Establishment of windbreaks reduces tree density per acre, thus contributing to yield losses.

In Florida, it is estimated that, with endemic citrus canker, total citrus production will decline by 13.4 million boxes of early-midseason varieties, 4.9 million boxes of Valencia oranges, 3.2 million boxes of red seedless grapefruit, and 2.1 million boxes of white seedless grapefruit. Productions of specialty varieties are expected to decline by 265,000 boxes of honey tangerines, 435,000 boxes of early tangerines, 540,000 boxes of navel oranges, 195,000 boxes of temple oranges, and 220,000 boxes of tangelos.

As a result, it is estimated that total production loss to Florida under an endemic citrus canker industry is equivalent to the loss of nearly 8 million commercial citrus trees. If the CCEP is allowed to proceed without further interruption, the number of eradicated commercial trees is expected to be less 
than 3 million. The number of eradicated residential door-yard trees is expected to be less than 1 million.

In Table 10, the estimated equivalent of the number of trees lost in an endemic citrus canker industry based on the estimated yield losses in boxes is shown. The estimated acreage loss is determined using the estimates of boxes per acre by variety reported in the Florida Agricultural Statistics Service's (FASS) Citrus Summary 1999-2000. Estimated trees per acre are derived by taking the reported number of trees divided by the bearing acreage (FASS, 2000).

Additional costs to production in an endemic citrus canker situation also lead to higher delivered-in costs reflected in additional copper applications, the establishment of windbreaks for grapefruit trees, and lower packout rates. The total estimated net change in the cost of producing marketable citrus varieties is estimated to be $\$ 169.25$ million annually (Table 11).

\section{Market Implications}

In a citrus industry in which citrus canker has become established, marketing implications severely alter the profile of the industry. Citrus canker significantly damages the appearance of the fruit, thereby reducing the proportion of fruit that is suitable for the fresh market. As a result, lower packout rates lead to higher retail prices in domestic and export markets. According to the results of the grapefruit model, the average F.O.B. prices of red seedless grapefruit for the United States, Canada, and Japan increase significantly in an endemic citrus canker situation from $\$ 7.60$ to $\$ 9.93$, from $\$ 7.80$ to $\$ 10.19$, and from $\$ 10.80$ to $\$ 14.16$, respectively. The average F.O.B. prices of white seedless grapefruit for the United States, Canada, and Japan increase significantly in an endemic citrus canker situation from $\$ 8.03$ to $\$ 10.34$, from $\$ 8.00$ to $\$ 10.30$, and from $\$ 11.00$ to $\$ 14.14$, respectively. F.O.B. prices per box increase significantly for specialty citrus as well. It is estimated that F.O.B. price per box for early tangerines, honey tangerines, and navel oranges will increase from $\$ 11.99$ to $\$ 22.65$, from $\$ 12.77$ to $\$ 24.12$, and from $\$ 8.89$ to $\$ 13.97$, respectively. The increase in price was not enough to offset the change in quantity for grapefruit, thereby reducing total
F.O.B. revenues. Specialty varieties were affected differently as revenues were estimated to increase.

\section{Trade Implications}

If citrus canker were to become endemic to Florida, it is likely that exports of fresh grapefruit to Europe will cease. In the case of Argentina in the late 1990s, fresh fruit intended for the European market had to be harvested from certified canker-free blocks. These blocks were inspected three times before harvest and a fourth time during packing. The certification process meant higher grove care costs and reduced grove sizes (Muraro, Roka, and Spreen, June 2001a). If Florida were to lose the European fresh market for red seedless and white seedless grapefruit, it would experience net revenue losses of $\$ 53$ million and \$2 million, respectively. Florida also stands to lose access to the fresh domestic markets of California and Texas. Possible net losses in revenue stemming from loss of access to these two markets as a result of endemic citrus canker were not incorporated into this analysis.

\section{Total Economic Implications}

Total annual benefits of the CCEP associated with changes in revenue and costs are shown in Table 11. In an endemic citrus canker situation, yield losses could contribute an estimated annual net revenue loss of approximately $\$ 84.9$ million ( $\$ 95.7$ million F.O.B. revenue loss less $\$ 10.8$ million on-tree revenue gain). Annual additional costs to production are estimated to be $\$ 169.2$ million. The estimated total net effect and economic impact of citrus canker is a negative $\$ 254.2$ million annually. Over the long run, this economic loss due to an endemic citrus canker situation is estimated to be nearly $\$ 2.5$ billion (EDIS FE531).

In this study, an attempt was made to place a value on the industry if it were to discontinue the CCEP by estimating the revenue loss and cost savings associated with the policy. The benefit-cost analysis of this study concluded that, at the present time, the benefits far outweigh the costs associated with the program.

The effects of the 2004 hurricane season add a new unknown in the CCEP economic analysis, since the citrus canker bacteria disease is spread by 
rain-driven wind. Results for the economic analysis were developed in June of 2004 before Hurricanes Charley, Francis, and Jeanne passed through Florida. Continuation of the CCEP beyond 2008 would require a new study to estimate the economic impact of the additional costs of the CCEP along with the losses incurred by Florida's citrus industry.

\section{References}

Animal and Plant Health Inspection Service (APHIS). 2003. Citrus Canker. Washington D.C.: United States Department of Agriculture. Available online at http://www.aphis.usda.gov/ppq/ep/citruscanker.

Brown, M.A., T.H. Spreen and R.P. Muraro. 1999. Fresh versus Processed Utilization of Florida Grapefruit. Journal of Food Distribution Research 30(3):22-32.

Florida Agricultural Statistics Service (FASS). 2000. Citrus Summary 1999-2000. Orlando, FL.

Gottwald, T.R., J.H. Graham, and T.S. Schubert. 2002. Citrus Canker: The Pathogen and Its Impact. Plant Health Progress doi: 10.1094/PHP-2002-0812-01-RV.

Graham, J.H. 2001. Varietal Susceptibility to Citrus Canker: Observations from Southern Brazil. Citrus Industry 82:15-17.

Graham, J.H. and T.R. Gottwald. 1991. Research Perspectives on Eradication of Citrus Bacterial Diseases in Florida. Plant Dis. 75:1193-1200.

Koizumi, M. 1985. Citrus Canker: The World Situation. In Citrus Canker: An International Perspective, edited by L.W. Timmer, pp. 2-7. Lake Alfred, FL: Citrus Research and Education Center, University of Florida.

McClain, E.A. 1989. A Monte Carlo Simulation Model of the World Orange Juice Market. Ph.D. Dissertation, Department of Food and Resource Economics, University of Florida, Gainesville, FL.

Muraro, R.P., J.W. Hebb, and E.W. Stover. 2000. Budgeting Costs and Returns for Indian River Citrus Production, 1999-2000. Economic Information
Report EI-01-07, Department of Food and Resource Economics, University of Florida, Gainesville, FL (December).

Muraro, R.P., F.M. Roka, and R.E. Rouse. 2000. Budgeting Costs and Returns for Southwest Florida Citrus Production, 1999-2000. Economic Information Report EI-00-07. Department of Food and Resource Economics, University of Florida, Gainesville, FL (December).

Muraro, R.P., F.M. Roka, and T.H. Spreen. 2001a. An Overview of Argentina's Citrus Canker Control Program. Electronic Data Information Source (EDIS) FE285. Department of Food and Resource Economics, UF/IFAS, University of Florida, Gainesville, FL (June).

Muraro, R.P., F.M. Roka and T.H. Spreen. June 2001b. Grower Costs of Having Citrus Canker in Florida. Electronic Data Information Source (EDIS) FE286. Department of Food and Resource Economics, UF/IFAS, University of Florida, Gainesville, FL (June).

Zansler, M.L. 2004. The Economic Impacts to an Industry Associated with an Invasive Species: The Case of Citrus Canker in Florida. Ph.D. Dissertation, Department of Food and Resource Economics, University of Florida, Gainesville, FL (August). 
Table 1. Estimated change in net on-tree revenues for Florida processed oranges associated with endemic citrus canker. (Source: EDIS FE533)

\begin{tabular}{|c|c|c|c|}
\hline \multirow[t]{2}{*}{ Variety } & \multicolumn{3}{|c|}{ Processed On-tree Revenues } \\
\hline & Without Citrus Canker & With Citrus Canker & Net Change in Revenue \\
\hline Early-Midseason & 391,410 & 371,071 & $(20,338)$ \\
\hline \multirow[t]{2}{*}{ Valencia } & 414,243 & 414,144 & $(99)$ \\
\hline & \multicolumn{2}{|c|}{ Estimated Net Change in On-Tree Revenue: } & $(20,437)$ \\
\hline
\end{tabular}

Table 2. Estimated change in net F.O.B. revenues for Florida processed oranges associated with endemic citrus canker. (Source: EDIS FE533)

\begin{tabular}{|cc|}
\hline \hline & Processed F.O.B. Revenues \\
Without Citrus Canker & With Citrus Canker $\quad$ Estimated Net Change in F.O.B. Revenue \\
\hline $1,171,670$ & $1,676,550$ \\
\hline \hline
\end{tabular}

Table 3. Estimated annual net change in the cost of production associated with endemic citrus canker in the Florida citrus industry for processed oranges. (Source: EDIS FE533)

\begin{tabular}{|c|c|c|c|}
\hline \multirow[t]{2}{*}{ Variety } & \multicolumn{3}{|c|}{ Total Processed Orange Production Costs } \\
\hline & Without Citrus Canker & With Citrus Canker & Net Revenue Change \\
\hline Early-Midseason & 574,628 & 582,814 & 8,186 \\
\hline \multirow[t]{2}{*}{ Valencia } & 433,183 & 443,120 & 6,171 \\
\hline & \multicolumn{2}{|c|}{ Estimated Net Change in Production Costs: } & 14,357 \\
\hline
\end{tabular}

Table 4. Estimated annual net change in on-tree revenues for fresh and processed red seedless and white seedless grapefruit associated with endemic citrus canker. (Source: EDIS FE534)

\begin{tabular}{|cccc|}
\hline \hline Variety & \multicolumn{2}{c|}{ On-tree Revenues } \\
& & - & \\
& Without Citrus Canker & With Citrus Canker & Net Revenue Change \\
\hline Fresh Market & & & \\
Red Seedless Grapefruit & 76,982 & 83,814 & 6,832 \\
White Seedless Grapefruit & 41,770 & 40,693 & $(1,077)$ \\
\hline Processed Market & & & \\
Red Seedless Grapefruit & 30,342 & 21,575 & $(8,767)$ \\
White Seedless Grapefruit & 39,078 & 28,812 & $(10,216)$ \\
\hline & Estimated Net Change in On-Tree Revenue: & $(13,229)$ \\
\hline \hline
\end{tabular}


Table 5. Estimated annual net change in world F.O.B. revenues for red seedless and white seedless grapefruit associated with endemic citrus canker. (Source: EDIS FE534)

\begin{tabular}{|c|c|c|c|}
\hline \multirow[t]{2}{*}{ Variety } & \multicolumn{3}{|c|}{$\begin{array}{l}\text { F.O.B. Revenues } \\
\$ 1,000\end{array}$} \\
\hline & Without Citrus Canker & With Citrus Canker & Net Change in Revenue \\
\hline \multicolumn{4}{|l|}{ Red Seedless Grapefruit } \\
\hline United States & 108,110 & 121,037 & 12,927 \\
\hline Canada & 16,271 & 18,332 & 2,061 \\
\hline European Union & 52,696 & -- & $(52,696)$ \\
\hline \multirow[t]{2}{*}{ Japan } & 53,989 & 39,364 & $(14,624)$ \\
\hline & \multicolumn{2}{|c|}{ Estimated Net Change in F.O.B. Revenue: } & $(52,333)$ \\
\hline \multicolumn{4}{|l|}{ White Seedless Grapefruit } \\
\hline United States & 11,949 & 13,401 & 1,452 \\
\hline Canada & 1,344 & 1,504 & 160 \\
\hline European Union & 2,034 & -- & $(2,034)$ \\
\hline \multirow[t]{2}{*}{ Japan } & 75,768 & 57,012 & $(18,756)$ \\
\hline & \multicolumn{2}{|c|}{ Estimated Net Change in F.O.B. Revenue } & $(\$ 19,177)$ \\
\hline
\end{tabular}

Table 6. Estimated annual net change in the cost of production of red seedless and white seedless grapefruit. (Source: EDIS FE534)

\begin{tabular}{|c|c|c|c|}
\hline \multirow[t]{2}{*}{ Variety } & \multicolumn{3}{|c|}{ Total Production Costs } \\
\hline & Without Citrus Canker & With Citrus Canker & Net Revenue Change \\
\hline \multicolumn{4}{|l|}{ Field Run } \\
\hline Red Seedless Grapefruit & 27,666 & 25,565 & $(2,101)$ \\
\hline White Seedless Grapefruit & 53,453 & 54,149 & 696 \\
\hline \multicolumn{4}{|l|}{ Packinghouse } \\
\hline Red Seedless Grapefruit & 365,299 & 411,370 & 46,071 \\
\hline White Seedless Grapefruit & 171,374 & 199,396 & 28,022 \\
\hline \multicolumn{3}{|c|}{ Estimated Change in Production Cost: } & 72,688 \\
\hline
\end{tabular}

Table 7a. Estimated annual net change in on-tree revenues for fresh specialty fruit associated with endemic citrus canker. (Source: EDIS FE534)

\begin{tabular}{|c|c|c|c|}
\hline \multirow[t]{2}{*}{ Variety } & \multicolumn{3}{|c|}{ On-tree Revenues } \\
\hline & Without Citrus Canker & With Citrus Canker & Net Revenue Change \\
\hline \multicolumn{4}{|l|}{ Fresh Market } \\
\hline Early Tangerines & 24,985 & 46,273 & 21,288 \\
\hline Honey Tangerines & 18,626 & 32,015 & 13,389 \\
\hline Navel Oranges & 23,162 & 31,645 & 8,483 \\
\hline Temples & 2,464 & 2,464 & 0 \\
\hline Tangelos & 4,085 & 4,085 & 0 \\
\hline \multicolumn{3}{|c|}{ Estimated Net Change in On-Tree Revenue: } & 43,160 \\
\hline
\end{tabular}




\begin{tabular}{|c|c|c|c|}
\hline \multirow[t]{2}{*}{ Variety } & \multicolumn{3}{|c|}{ On-tree Revenues } \\
\hline & Without Citrus Canker & With Citrus Canker & Net Revenue Change \\
\hline \multicolumn{4}{|l|}{ Processed Market } \\
\hline Early Tangerines & 1,754 & 2,396 & 642 \\
\hline Honey Tangerines & 1,117 & 1,860 & 743 \\
\hline Navel Oranges & 598 & 962 & 365 \\
\hline Temples & 2,507 & 2,301 & $(206)$ \\
\hline \multirow[t]{2}{*}{ Tangelos } & 1,464 & 1,244 & $(220)$ \\
\hline & Estimated Net Chan & On-Tree Revenue: & 1,323 \\
\hline
\end{tabular}

Table 8. Estimated annual net change in F.O.B. revenues for specialty citrus fruit associated with endemic citrus canker. (Source EDIS FE535)

\begin{tabular}{|c|c|c|c|}
\hline \multirow[t]{2}{*}{ Variety } & \multicolumn{3}{|c|}{ F.O.B. Revenues } \\
\hline & Without Citrus Canker & With Citrus Canker & Net Change in Revenue \\
\hline Early Tangerine & 63,067 & 71,476 & 8,409 \\
\hline Honey Tangerine & 45,717 & 51,812 & 6,096 \\
\hline Navel Oranges & 63,848 & 60,200 & $(3,648)$ \\
\hline \multicolumn{3}{|c|}{ Estimated Net Change in F.O.B. Revenue: } & 10,856 \\
\hline
\end{tabular}

Table 9. Estimated annual net change in the cost of production of specialty fruit. (Source: EDIS FE535)

\begin{tabular}{|c|c|c|c|}
\hline \multirow[t]{2}{*}{ Variety } & \multicolumn{3}{|c|}{ Total Production Costs } \\
\hline & Without Citrus Canker & With Citrus Canker & Net Revenue Change \\
\hline \multicolumn{4}{|l|}{ Packinghouse } \\
\hline Early Tangerines & 58,194 & 71,216 & 13,022 \\
\hline Honey Tangerines & 88,131 & 105,862 & 17,731 \\
\hline Navel Oranges & 122,472 & 156,784 & 34,312 \\
\hline Temples & 12,696 & 16,434 & 3,738 \\
\hline Tangelos & 31,755 & 45,154 & 13,399 \\
\hline \multicolumn{3}{|c|}{ Estimated Change in Production Cost: } & 82,201 \\
\hline
\end{tabular}


Table 10. Equivalent tree loss under endemic citrus canker based on estimated yield loss.

\begin{tabular}{|c|c|c|c|c|c|}
\hline Variety & $\begin{array}{l}\text { Estimated } \\
\text { Yield Loss }\end{array}$ & $\begin{array}{c}\text { Boxes per } \\
\text { Acre }^{\mathrm{a}}\end{array}$ & $\begin{array}{c}\text { Estimated } \\
\text { Acreage Loss }\end{array}$ & $\begin{array}{c}\text { Trees per } \\
\text { Acre }^{\mathrm{a}}\end{array}$ & $\begin{array}{c}\text { Equivalent Lost } \\
\text { Trees }\end{array}$ \\
\hline & (1,000 boxes) & & (1,000 acres) & & $(1,000$ trees $)$ \\
\hline Early-Midseason & 13,400 & 437 & 30.664 & 127 & 3,881 \\
\hline Valencia & 4,950 & 335 & 14.776 & 135 & 1,995 \\
\hline Red Seedless Grapefruit & 3,190 & 465 & 6.860 & 112 & 765 \\
\hline White Seedless Grapefruit & 2,563 & 485 & 4.309 & 101 & 434 \\
\hline Early Tangerines & 265 & 298 & 0.889 & 150 & 133 \\
\hline Honey Tangerines & 435 & 253 & 1.719 & 151 & 260 \\
\hline Navels & 540 & 240 & 2.250 & 127 & 285 \\
\hline Temples & 195 & 336 & 0.580 & 113 & 66 \\
\hline Tangelos & 220 & 195 & 1.128 & 123 & 139 \\
\hline \multicolumn{5}{|c|}{ Total Estimated Tree Loss Equivalent: } & 7,956 \\
\hline
\end{tabular}

Table 11. Summary of estimated net effect and economic impact of citrus canker on revenues and costs for Florida citrus.

\begin{tabular}{|c|c|c|}
\hline Estimations & Net Change & Total Net Change \\
\hline & $\$ 1,000$ & $\$ 1,000$ \\
\hline \multicolumn{3}{|l|}{ Estimated Annual Net Change (Loss) in On-Tree Revenue: } \\
\hline Processed Oranges & $(20,437)$ & \\
\hline Fresh/Processed Grapefruit & $(13,229)$ & \\
\hline Fresh/Processed Specialty Fruit & 44,483 & \\
\hline Total Annual Net Change in On-Tree Revenue & & 10,817 \\
\hline \multicolumn{3}{|l|}{ Estimated Annual Net Change (Loss) in F.O.B. Revenue: } \\
\hline Processed Oranges & $(35,120)$ & \\
\hline Fresh/Processed Grapefruit & $(71,510)$ & \\
\hline Fresh/Processed Specialty Fruit & 10,856 & \\
\hline Total Annual Net Change (Loss) in F.O.B. Revenue & & $(95,774)$ \\
\hline \multicolumn{3}{|l|}{ Estimated Annual Net Change (Increase) in Costs: } \\
\hline Processed Oranges & $(14,357)$ & \\
\hline Fresh/Processed Grapefruit & $(72,688)$ & \\
\hline Fresh/Processed Specialty Fruit & $(82,201)$ & \\
\hline Total Annual Net Change (Increase) in Costs & & $(169,246)$ \\
\hline Total Annual Net Effect and Economic Impact (Loss) & & $(254,203)$ \\
\hline
\end{tabular}

